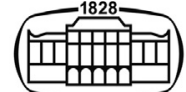

AKADÉMIAI KIADÓ

Pollack Periodica

An International Journal

for Engineering and

Information Sciences

$16(2021) 3,139-145$

DOI:

10.1556/606.2021.00362

(c) 2021 The Author(s)

\section{ORIGINAL RESEARCH}

PAPER

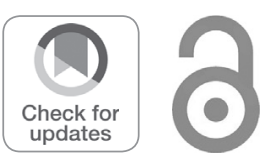

Corresponding author.

E-mail: hhhaoff@gmail.com

\title{
Intervention and renewal - Interpretation of installation art in urban public space
}

\author{
Honghao $\mathrm{He}^{1 *} \odot$, Mengyang $\mathrm{Wu}^{1}$ and Janos Gyergyak ${ }^{2}$
}

\author{
${ }^{1}$ Marcel Breuer Doctoral School, Faculty of Engineering and Information Technology, University of \\ Pécs, Boszorkány u. 2, H-7624, Pécs, Hungary \\ ${ }^{2}$ Department of Architecture and Urban Planning, Faculty of Engineering and Information \\ Technology, University of Pécs, Boszorkány u. 2, H-7624, Pécs, Hungary
}

Received: December 31, 2020 • Revised manuscript received: March 18, 2021 • Accepted: March 30, 2021 Published online: May 26, 2021

\begin{abstract}
The manifestation of installation art is becoming more and more diversified and closer to the people in the urban public space. It forms an interactive environment with the urban space. This article discusses the relationship between installation art and urban renewal from the perspective of art intervention in urban public spaces. Through the observation, investigation and case analysis of installation art in the city, above all, it summarizes the development context of installation art, then elaborates the intervention strategies and characteristics of installation art in urban public space, analyzes the role of installation art in urban public space, and finally summarizes the value of installation art to urban renewal.
\end{abstract}

\section{KEYWORDS}

installation art, urban public space, urban renewal, art intervention

\section{DEVELOPMENT AND CURRENT SITUATION OF INSTALLATION ART}

\subsection{The evolution of installation art}

French artist Marcel Duchamp produced works "Bicycle Wheel" and "Fontain" in 1951 and 1950, respectively, [1, 2]. These works of art have attracted the attention of avant-garde artists and the art criticism industry. At that time, installation art works admired nature, randomness, freedom and subverted traditional creative concepts [3]. Then installation art emerged in the 1960s, and there have even been museums dedicated to installation art. With the development of postmodernism, from the 1960s to the early 1990s, installation art continued to emerge. They used all the artistic methods and materials they needed to start artistic creation in combination with indoor spaces. Then installation artists began to make art exhibitions out of the museum's same type of collection and education space. They used abandoned factory buildings, simple warehouses, street sides, and walkway corners as installation art exhibition venues, embellishing the urban landscape and becoming the daily life of the general public. Allow the public to watch artworks anytime and anywhere in their daily lives (Fig. 1).

From the 1980s to the 1990s, the media and topics involved in installation art have been very extensive, involving many aspects of contemporary people's lives and thinking, especially the hot issues that contemporary people care about, for example environmental protection and world peace, multiple cultures, ethnic conflicts, etc. With the development and progress of science and technology, the materials and technologies involved in installation art are constantly updated, for instance multimedia technology, the Internet, and so on. The topic presented by installation art is no longer a simple space beautification, but may convey the origin of a thing, or a national shout, or an attitude of an event, or a certain historical 


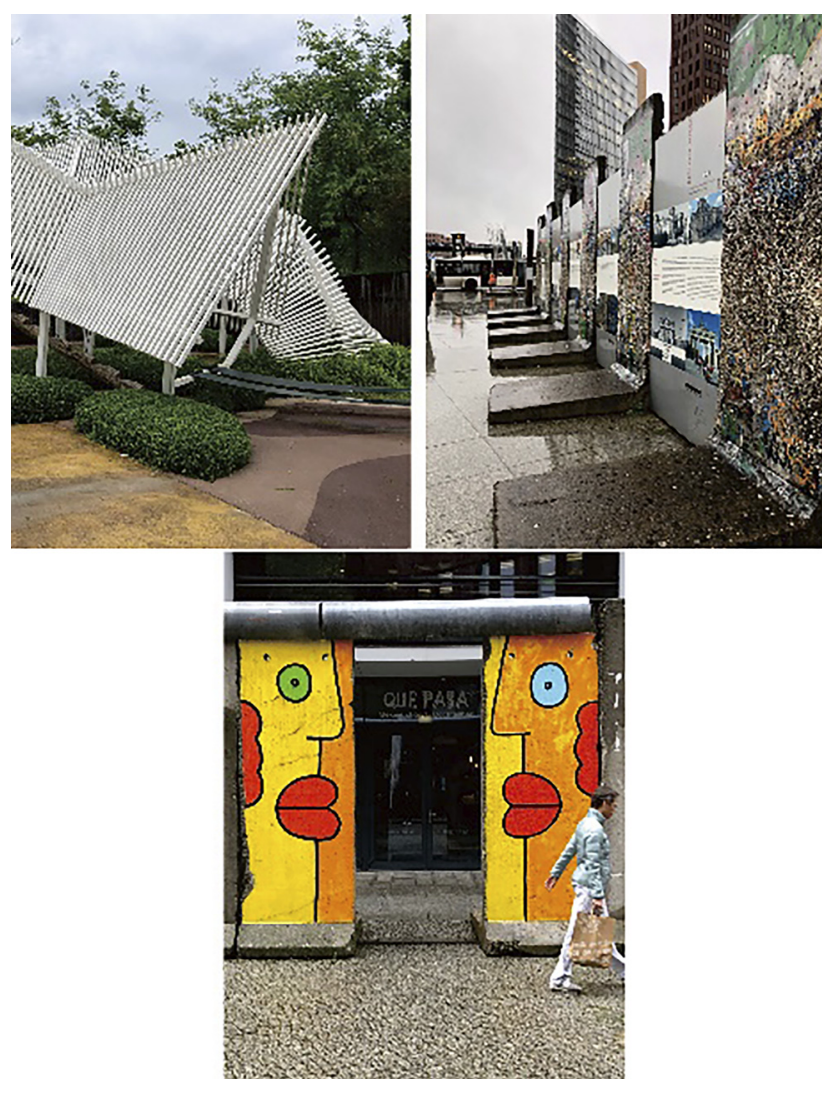

Fig. 1. Installation art in urban public space (Source: Honghao He)

scene. Installation art better integrates the concept of "site, material, emotion" and enriches people's enjoyment of public space [4].

\subsection{Installation art and urban public space}

1.2.1. Installation art in urban renewal. With the continuous evolution of social changes, installation art has become more and more abundant in forms, whether in urban square space or street space; it can become a place for installation art expression. It can be seen that installation art is a flexible strategy of art intervention in space, bringing multiple experiences to urban public spaces. The rich presentation forms make installation art attract more and more people's attention, and it appears more and more frequently in urban public spaces. Whether it is commercial space, city square, street space, etc., it can attract people's attention to varying degrees and get involved. This article discusses installation art in the renewal of urban public space, and explores the role of installation art in the transformation of urban public space from incremental development to stock development.

\subsubsection{Installation art from the perspective of urban renew-} al. The intervention of installation art in urban public spaces with different attributes will produce different results and reflect different characteristics and influences. This article explores and interprets the characteristics and functions of installation art in public space from the perspective of urban public space renewal needs. From a relatively micro perspective, discuss how installation art intervenes and play its role in the renewal of urban public spaces, interpret the impact of installation art on urban public spaces, and seek more diverse artistic interventions in the existing urban public space construction models Space renewal means.

\section{FEATURES OF INSTALLATION ART}

Installation art utilizes the expression methods of modern art and the great richness of materials to update traditional artistic concepts and forms. The comprehensive use of multiple art forms makes the performance characteristics of works diversified. It is difficult to define the characteristics of installation art from the category of a pure art work. It involves the intersection of multiple dimensions, for example creative thinking, realistic environment, historical changes, and so on [5]. From the category of urban public space renewal, this article summarizes the characteristics of installation art in the intervention and renewal of urban public space.

\subsection{Intervention}

Installation art often intervenes in urban public spaces in an artistic way, and is attached to the public space in a new state. Generally, the space will not be remodeled and beautified too much, and the space is mainly updated. As a slight way to update public space, installation art reduces excessive intervention in the original public space, which is conducive to the continuation of urban texture and culture, and at the same time can meet the needs of art intervention space.

\subsection{Diversity}

Installation art not only has a rich diversity in the use of materials and media, but also has a variety of expressions in the renewal of public spaces. Installation art can not only achieve a harmonious state with public space for renewal, but also intervene in a contradictory phenomenon with public space. You can also borrow the diversity of installation art to alienate the space, making the public space different from the previous space state.

\subsection{Suggestive}

Installation art can also be used as a medium and container for artistic expression [6]. It can accommodate the content that the author and the audience hope to implant, and it carries a certain kind of thought. At the same time, the form of expression created by installation art does not directly tell, but has a certain suggestion and mapping function, and different ideas are generated due to the different life experiences of people watching. This is also the charm of installation art, which is different from traditional art expressions.

\subsection{Interactivity}

With the development of science and technology, installation art is constantly making new attempts and changes, 
especially digital media and virtual technology bring interesting and rich interactive means to installation art [7]. Therefore, installation art uses these new media and technologies to present diversified forms of interaction, so that the audience is no longer passively participating in the public space, and actively participates through the interaction of the installation art in the space. At the same time, in the process of installation art interaction, the audience changes from original viewers to art designers through interaction with different materials and media. Interactivity strengthens the audience's sense of participation in public space and strengthens the audience's sense of presence in urban public spaces.

\subsection{Openness}

Installation art intervenes in the public space to express multiple forms, which also shows its inclusiveness and openness. It can not only accommodate the different ideas and viewpoints of the designer and the audience, but also allow different people to participate in the interaction of the installation, and attract different people to participate in the public life in the public space. This is also in line with the publicity advocated by urban public spaces, and installation art creation itself originates from life, and finally combines with public spaces to return to people's living environment [8].

\section{STRATEGIES FOR INSTALLATION ART TO INTERVENE IN URBAN PUBLIC SPACES}

\subsection{Create a new visual experience}

With the passage of time, urban public spaces gradually appear to be functionally aging, idle, or even abandoned. The traditional spatial experience gradually becomes boring and monotonous, causing people's interest in spatial experience to decrease. The renewal of installation art in these spaces can create novel spaces, contrast with the original space in terms of visual experience, and at the same time form an impactful space image, enabling people to transcend the cognition of traditional spaces and break through the boundaries of the original public space landscape design. Installation art is an art category with visual impact [9]. Artists often boldly use gorgeous colors, exaggerated shapes, diverse material choices, and beyond conventional ideas to create a rich visual experience in their designs, which makes the form of installation art also extremely tense, often forming with urban public spaces A contrasting visual experience, for example, static and dynamic, abstract and reality, variation and routine, etc. An underground space outlet on the street in Milan, Italy, uses the combination of ribbons and wind to form an installation art with very interesting visual experience in the public space, ingeniously transforming the idle space on the roadside into a dynamic visually interesting installation (Fig. 2).
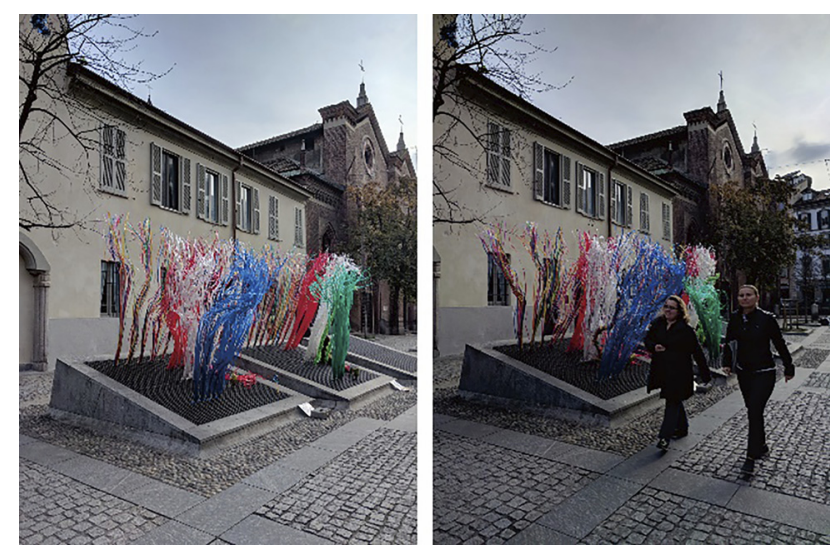

Fig. 2. Ribbons fluttering in the streets of Milan, Italy (Source: Honghao He)

\subsection{Form a new interactive environment}

When installation art intervenes in urban public spaces to bring visual experience, it also brings new spatial experience and interaction methods. The development of contemporary new media, networks and high-tech provides more possibilities for the interaction between people and space. The creation of diversified installation art depends on the combination of emerging science and technology. It has changed the way of participating in interaction in traditional public spaces, and with the support of multimedia technology, it can better attract the public to participate in interaction (Fig. 3). Through interaction with installation art, people can get interactive feedback instantly, enriching space experience and fun.

Installation art intervenes in public space to change the way the public passively participates in public life in the past. The public is no longer a mere viewer or visitor [10]. They need to actively participate in interaction to make installation art works meaningful and complete. With the help of installation art, the public space has transformed the public's role into a designer or creator. The installation not only induces the public's physical participation, but also forms a new interaction with the public space through the exchange of roles, making it psychologically accessible. More resonance and feelings are also consistent with the public's desire to participate in the construction of urban public spaces. Installation art intervenes in urban public spaces to form a new interactive environment, which not only connects the

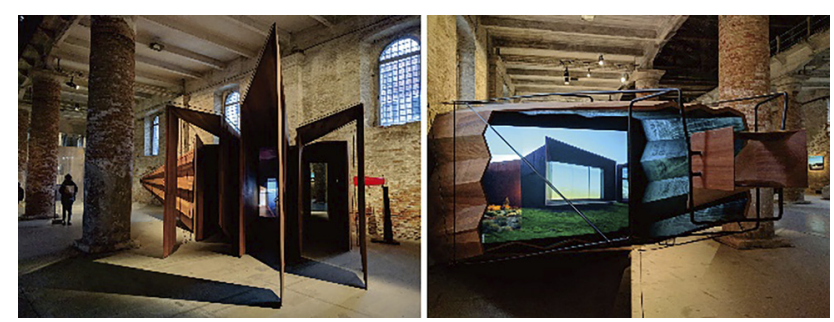

Fig. 3. The combination of multimedia and art installations in the 2018 Venice Biennale (Source: Honghao He) 
emotional communication between people and the environment, but also promotes the exchange and communication between people and the city [11].

\subsection{Create a mark and memory}

As a means of renewal of artistic intervention in space, installation art is different from some other means of renewal of space. Installation art has diversified forms of expression in public spaces, and can interact with multimedia technology and high technology to form a distinctive and novel form of artistic expression. Installation art not only becomes the visual focus of public space, attracting public attention, but also can be shaped into iconic landscape in the space, enhance the recognition of public space, and easily leave a deep impression on people (Fig. 4) emphasizing and highlighting the individuality of urban public space renewal, and avoid renewal methods that tend to be homogeneous in the renewal process.

Installation art intervenes in urban public spaces on the one hand to use enhanced visual experience to create iconic landscapes and deepen people's memory; on the other hand, installation art conveys its meaning through interaction and suggestion. These meanings can awaken people's attention to space, tell the problems faced by the space, or tell a related historical memory of the space. The awakened memories and the conveyed meanings increase the emotional communication between people and the space, just as

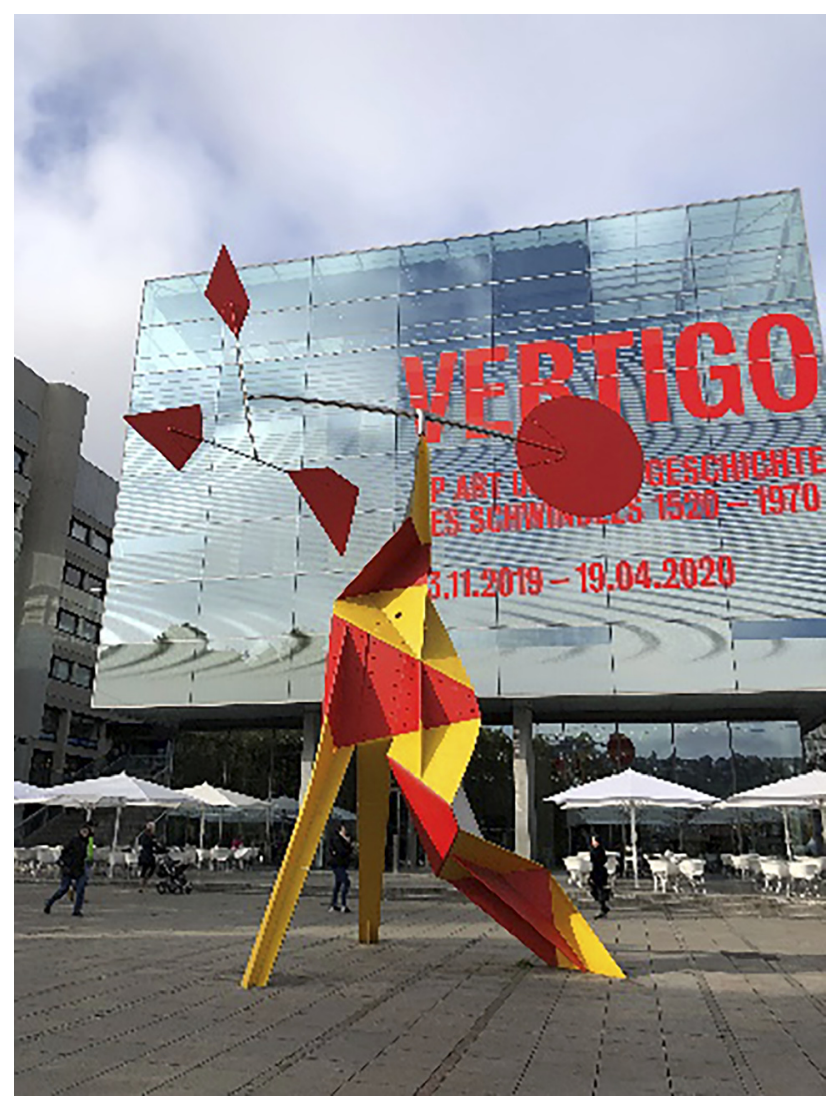

Fig. 4. Colorful art installation on the streets of Stuttgart, Germany (Source: Honghao $\mathrm{He}$ )
Anthony Johnson put forward a point of view, the installation can create a novel environment, promote the memory of the audience, and form a certain life experience in the form of memory. The formation of public life experience further strengthens the understanding of the installation [12].

\subsection{Create a public art event}

When installation art appears as a kind of public art in urban public space, it will first bring a fresh and curious feeling, and make the usual calm public space appear in a different state. The change of the space state can make people become more sensitive from the accustomed feeling, and start to pay attention to the changes of public space again. The birth of installation art works to the intervention of public space belongs to the process of designer's artistic creation. The designer integrates his personal experience of acquiring knowledge, thinking, and insights in the space into installation art and intervenes in urban public space [13]. Installation art is constantly fermenting in public space. Both artists and the public will discuss and pay attention to the changes of art intervention space, thus forming public art events that attract the attention of the art world and society. It not only uses the appeal of art to change the original normal spatial state, but also gradually forms an effect that focuses on installation art and space. The artistic events created by installation art allow people to think about the deeper meaning behind the work. This is also the positive significance of installation art's involvement in urban public spaces. Through a public art event, people can pay attention to the problems of public space, deepen the public's understanding of space, and clarify future space use needs (Fig. 5).

\section{THE ROLE OF INSTALLATION ART IN RENEWING URBAN PUBLIC SPACE}

\subsection{The role of attracting people}

In the face of some urban public spaces with aging, abandoned and unused functions, these spaces have gradually been ignored and used by the public, and fewer and fewer people use the space, even no one patronizes them. The intervention of installation art in urban public spaces can help to change the original space environment, bring different visual experiences to the public through rich expressions, attract people's attention, and add a sense of freshness to the space. This will not only make people notice the idle space they take for granted, but also attract more people into the space through the stimulation of visual experience.

Installation art intervenes in the "public art events" formed by urban public spaces, not only attracting the attention of the media, artists, and the public, but also creating topics of public opinion. It increases the common topics of people's discussion and communication in public 


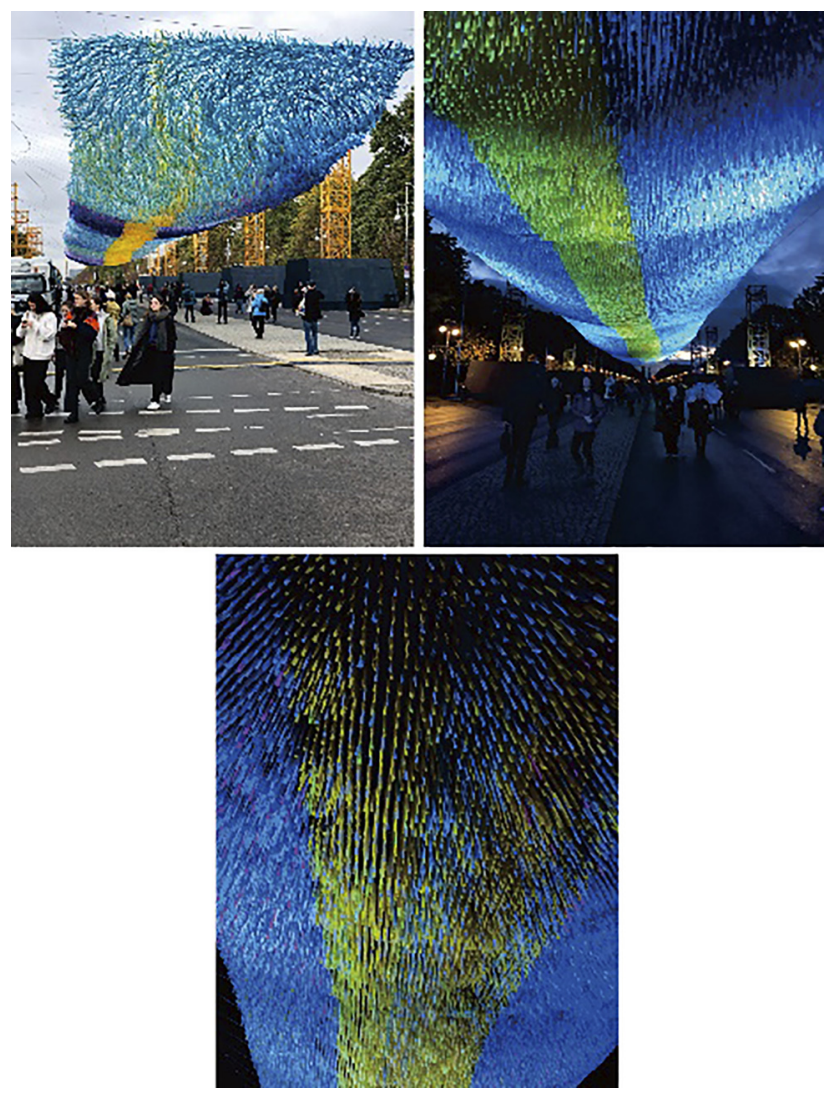

Fig. 5. An art installation commemorating the 30th anniversary of the fall of the Berlin Wall at the Brandenburg Gate in Germany (Source: Honghao He)

space activities, and creates opportunities for communication to extend the time people stay in the space. At the same time, the topic of installation art's intervention in the space will gradually ferment with the development of time, and the continuous diffusion and dissemination of information will help attract more people to visit the space.

The combination of installation art, multimedia and high technology has created some interesting spatial interactive experiences. The novel interactive methods change the traditional way people experience space and break the previous way of public participation in public life. The interactive way of installation art attracts people to actively explore and experience, so that the audience can receive information in a dynamic environment, which is different from the traditional static space experience, and can also attract more public participation and stop to communicate.

\subsection{Convey the spirit of the place}

The intervention of installation art in the urban public space is not simply to beautify the space environment. The installation itself has the ability of statement like "text" [14]. The renewal of public space is not blindly renewing the environment and functions. Sometimes it is also necessary to renew the public's concept of space renewal, so that the audience can know the past, current state and future use needs of the space. Installation art can use multimedia and high-tech science and technology to display and narrate urban public space related information, so that the public can understand the reasons for the formation of the current space, pay attention to the essential issues in space renewal, and better participation in future space renewal and construction.

As a work of art, installation art contains the designer's emotions and insights. The use of a combination of abstraction and reality obscures the emotions in the work, triggering people's multiple thinking. Urban public space is an important place for people's public life. The space contains rich emotions and culture, which influence people subtly [15]. The novel installation art allows designers to have more choices and ideas. They can use the installation to give the space rich emotions and meanings, and avoid straightforward and plain way to tell the public. This method is conducive to people's thinking about the meaning conveyed by installation art, and deepens people's impression and perception of space. Sometimes installation art magnifies the problem of public space renewal with the help of allegorical methods, so that people are more intuitively aware of the problems in the space, so that they can reflect and pay attention to create better basic conditions for public space renewal.

\subsection{Update place function}

Relying on the form of expression, interactive methods, and novel effects of installation art is not enough to achieve the effect of spatial renewal, and it is easy to cause the illusion of short-term spatial renewal. Public space is an important place for people to participate in public life. It is necessary to provide the public with necessary functional services and meet the use needs to attract people to use and update the space. Installation art not only changes the way people experience the space, but also has the function of updating and adding to meet the needs of public space, inspiring the public's sensory experience in the space.

Installation art helps urban public spaces to enhance vitality and renewal functions. The improved public space environment allows the public to enjoy the services provided by urban public spaces and attracts more people willing to participate in public life. Therefore, the installation art is more like a catalyst in the renewal. Through intervention, the urban node space is activated to form the radiation effect of the public space, which promotes the business, residence, and life around the space, and makes the surrounding environment of the public space better. There are many development possibilities, and it can also improve the service functions around public spaces. Installation art not only renews the use function of public space, but also forms a radiation effect to improve people's space environment and quality of life.

\subsection{Micro-update strategy of artistic intervention}

The construction of urban public space has changed from an incremental development model to a stock development model. In this context, many cities have begun to try to find 
a bottom-up urban public space renewal model, and analyze the characteristics and problems of the space and require some artistic intervention programs to stimulate the vitality of the space and achieve the renewal of the public space. Installation art is also a strategy of artistic intervention in the renewal of public space. For example, it can increase the use of functions, interact with each other, and create novel spaces. This strategy is different from the traditional update mode. It does not need to update the original space completely. Instead, it performs a partial update for the space problem through analysis. For instance, a micro-update mode can effectively retain the original texture of the space and daily life scenes and effectively control construction costs, resource consumption, and shorten construction time. At the same time, for traditional public spaces, installation art appears in "unconventional" or unconventional forms of expression, which is extremely easy to attract people's attention and public opinion, so as to achieve the purpose of public space renewal and stimulate more urban public space renewal possibilities.

\subsection{Sustainable use of materials}

Installation art is different from other artistic methods. The selection and use of materials often involves the artistic treatment of items and wastes in daily life to form installations [16]. These objects have imprints of people's lives, and can make the device more easily resonate with public perception. In urban development, some abandoned or unused public spaces have become gathering places for "garbage", but in the eyes of the public, waste products often become materials for reuse in installation art performance. It can not only help the city digest waste that is regarded as worthless, but also highlight the value of recycling and reuse of materials, and give materials new landscape functions and aesthetic values through installation art. At the same time, the effective use of "garbage" in these cities can not only reduce construction costs to achieve the purpose of environmental protection, but also combine installation art to imply that people should treat and protect the environment of urban public spaces. This feature of installation art in the renewal of urban public space also coincides with the concept of sustainable development proposed in the development of urban construction. In the sustainable concept of installation art, it utilizes the limited resources in the original space, preserves the texture of the city's past and continues the material form and living environment of the space, and guides people to more easily experience the spirit of the public space.

\section{CONCLUSION}

The rise and development of installation art has gradually shifted from indoor exhibition spaces to outdoor urban public spaces. Advances in science and technology have also had an important impact on installation art. Its various forms of expression, rich use of materials, and unconstrained ideas have brought to the city and the public an unprecedented visual impact and spiritual experience. The practice of installation art in urban public space is closely related to the improvement of modern science and technology and the level of urbanization. At the same time, the improvement of the public's aesthetic and cognitive ability of art has also promoted the intervention of installation art in the development of urban public space. The intervention of installation art in urban public space is a trend in urban development. It uses different forms of expression to connect urban space with the public, creating a new space-art-people interaction, breaking the traditional way of spatial cognition.

This article explains that installation art, as a form of public art, intervenes in urban public space, and analyzes the performance characteristics of installation art, the ways of combining space and its role from the perspective of renewing public space. Through explaining and analyzing the role of installation art in the renewal of urban public space, it provides diversified ways for public space renewal, and at the same time provides reference and reference for the construction of urban public space in the future, so that urban public space can meet the public's future use needs. Therefore, installation art plays an active role in the renewal of urban public spaces, activates the vitality of idle and abandoned public spaces in the city, improves the environment of public life, and can create more interesting, flexible and individual urban public spaces.

\section{ACKNOWLEDGEMENT}

I am heartfelt thanks to all the teachers who have helped me. I am particularly grateful to Janos Gyergyak for providing the recommendations that has broadened my horizons. At the same time, I am grateful to Mengyang Wu for writing and correcting the paper together with me, and putting forward many enlightening opinions.

\section{REFERENCES}

[1] M. Duchamp, Bicycle Wheel. New York: MoMA Learning, 1951.

[2] M. Duchamp, Fountain. New York: Philadelphia Museum of Art, 1950.

[3] Y. Jun, "Study of landscape design's application from installation art” (in Chinese), MSc Thesis, Beijing Forestry University, 2012.

[4] W. Jinsi, "Research on the way of integrating installation art into landscape design of urban public space" (in Chinese), MSc Thesis, Chongqing University, 2016.

[5] L. Huiyu, "Analysis of the relationship between installation art, the masses and the city in contemporary times" (in Chinese), Mingrifengshang, no. 12, pp. 184-185, 2020.

[6] M. Xiaoxiang, "Discussion on the media application, media communication and artistic language of new media installation art” (in Chinese), Aesthetics Art Res., no. 4, pp. 153-155, 2019. 
[7] G. Jacucci, A. Spagnolli, A. Chalambalakis, A. Morrison, L. Liikkanen, S. Roveda, and M. Bertoncini, "Bodily explorations in space: Social experience of a multimodal art installation," in Proceedings of the 12th IFIP TC 13 International Conference on Human-Computer Interaction, Uppsala, Sweden, Aug. 24-28, 2009, 2009, vol. 2, pp. 62-75.

[8] J. Sharp, V. Pollock, and R. Paddison, "Just art for a just city: Public art and social inclusion in urban regeneration," Urban Studies, vol. 42, no 5-6, pp. 1001-1023, 2005.

[9] J. H. Reiss, From Margin to Center: The Spaces of Installation Art. Cambridge, MA and London, England: MIT Press, 2001.

[10] W. Di, "The research of installation art's interactive applications on urban landscape design" (in Chinese), MSc Thesis, Donghua University, 2014.

[11] C. Zigui, "Development of interactive installations in China public spate" (in Chinese), MSc Thesis, China Academy of Art, 2014
[12] S. Shengyin, "Integration and compatibility: Interpreting the "uncertainty" and "implication" of device art" (in Chinese), Hundred Schools in Arts, no. 3, pp. 216-219, 2010.

[13] M. Pelowski, E. Specker, G. Gerger, H. Leder, and L. S. Weingarden, "Do you feel like I do? A study of spontaneous and deliberate emotion sharing and understanding between artists and perceivers of installation art," Psychol. Aesthet. Creativity Arts, vol. 14, no. 3, pp. 276-293, 2020.

[14] J. Gyergyak, "Thoughts from the dynamical changing city, Shanghai," Pollack Period., vol. 11, no. 3, pp. 27-42, 2016.

[15] P. Guinard and A. Margier, "Art as a new urban norm: Between normalization of the City through art and normalization of art through the city in Montreal and Johannesburg," Cities, vol. 77, pp. 13-20, 2018.

[16] S. Miccoli, F. Finucci, and R. Murro, "A direct deliberative evaluation method to choose a project for Via Giulia, Rome," Pollack Period., vol. 10, no. 1, pp. 143-153, 2015. 